\title{
Biomedical Studies on Solvent Refined Coal (SRC-II) \\ Liquefaction Materials: \\ A Status Report
}

October 1979

Prepared for the U.S. Department of Energy under Contract EY-76-C-06-1830

Pacific Northwest Laboratory Operated for the U.S. Department of Energy by Battelle Memorial Institute 
NOTICE

This report was prepared as an account of work sponsored by the United States Government. Neither the United States nor the Department of Energy, nor any of their employees, nor any of their contractors, subcontractors, or their employees, makes any warranty, express or implied, or assumes any legal liability or responsibility for the accuracy, completeness or usefulness of any information, apparatus, product or process disclosed, or represents that its use would not infringe privately owned rights.

The views, opinions and conclusions contained in this report are those of the contractor and do not necessarily represent those of the United States Government or the United States Department of Energy.

PACIFIC NORTHWEST LABORATORY

operated by

BATTELLE

for the

UNITED STATES DEPARTMENT OF ENERGY

Under Contract EY-76-C-06-1830

Printed in the United States of America

Available from

National Technical Information Service

United States Department of Commerce

5285 Port Royal Road

Springfield, Virginia 22151

Price: Printed Copy s

$\therefore$ Microfiche $\$ 3 . \infty$

NTIS

-Pages Selling Price

$001-025 \quad \$ 4.00$

026-050 \$4.50

$051-075=\$ 5.25$

$076.100 \quad \$ 6 . \infty$

$101-125 \quad 56.50$

$126-150 \quad 57.25$

$151-175 \quad 58.00$

$176-200 \quad 59.00$

$207.225 \quad 59.25$

$225-250 \quad 59.50$

$251.275 \quad 510.75$

$276-300 \quad 511.00$ 
PNL-3189

BIOMEDICAL STUDIES ON SOLVENT REFINED COAL (SRC-II)

LIQUEFACTION MATERIALS: A STATUS REPORT

October 1979

Prepared for

the U.S. Department of Energy under Contract EY-76-C-06-1830

Pacific Northwest Laboratory

Richland, Washington 99352 


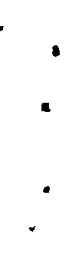


CONTENTS

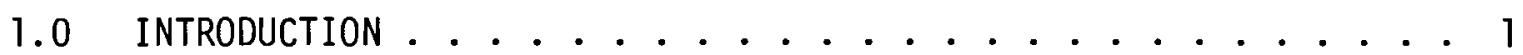

2.0 REPRESENTATIVES OF SRC-II PILOT PLANT SAMPLES. . . . . . . 5

3.0 RELATIONSHIP OF PILOT PLANT SRC-II SAMPLES

TO DEMONSTRATION PLANT MATERIALS . . . . . . . . . . . 13

4.0 SYNOPSIS OF BIOMEDICAL EXPERIENCE

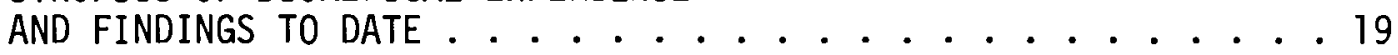

5.0 IMPLICATIONS OF EXPERIENCE AND FINDINGS TO DATE. . . . . . 53 



\section{FOREWORD}

This document represents the combined efforts of three organizations. Sections $1.0,2.0$ and 3.0 are due primarily to the efforts of the staffs of Environmental Research and Technology, Inc. and Pittsburg and Midway Coal Mining Co. Section 4.0 represents the efforts of the staff of Battelle at Pacific Northwest Laboratory (PNL), while Section 5.0 represents the efforts of staff from all three organizations.

This document is intended to summarize the biomedical research effort at PNL and includes sufficient technical data to provide a flavor of the results of that effort. Much detail was necessarily omitted in order to avoid producing an unduly long document. For those who are interested in further details about the research findings, an Appendix which provides additional information is being published as Part II of this document. The Appendix is referred to in Section 4.0 of the text, and will be available, upon request, in the near future. 


\section{EXECUTIVE SUMMARY}

This technical report summarizes the results of the biomedical research effort at Pacific Northwest Laboratory on solvent refined coal (SRC) materials obtained from the pilot plant at Fort Lewis, WA. The process conditions under which the PNL samples were produced are discussed as is the relevance of these samples to demonstration/commercialscale operations.

Samples of light, middle, and heavy distillates (LD, MD, and HD) were obtained from the Fort Lewis pilot plant during operation in the SRC-II mode. The samples were obtained from the raw product distillation section of the plant and contain components produced not only during stable operation, but also during plant startup and during upset conditions. Thus, the samples were representative of materials produced during a spectrum of operating conditions. As such, they bear a generic relationship to materials to be produced in a demonstration-scale facility.

The above-described samples as well as samples of raw shale oil, crude petroleums, and some SRC-I materials were evaluated for biological activity in several different systems: (1) microbial mutagenesis coupled to chemical characterization efforts, (2) in vitro mammalian cell toxicity and transformation, (3) epidermal carcinogenesis (skin painting) in mice, (4) acute and subchronic oral toxicity in rats, (5) developmental toxicity in rats, and (6) dosimetry and metabolism in rats.

Microbial mutagenesis (Ames assay) was used as the first step in a tier approach (sequential assays in progressively more complex biological systems). This system is commonly used as a rapid, inexpensive screening 
procedure for potential carcinogens. Heavy distillate (SRC-II) and process solvent (PS; SRC-I), which are high boiling point materials, showed significant mutagenic activity while lower boiling fractions from both processes were inactive. Crude petroleum was also inactive while raw shale oil showed only a low level of activity. Chemical characterization studies suggested that 3- and 4-ring primary aromatic amines are responsible for a large fraction of the mutagenic activity of $H D$ and PS.

Studies of transformation (altered morphologic and biochemical properties which permit unrestricted growth) were performed in cultured mammalian cells (2nd step in tier approach). These studies showed that materials exhibiting a positive effect in the Ames system also caused mammalian cell transformation. In addition, some materials which were negative in the Ames assay showed a low level of activity in the cell transformation assay. These included petroleum crudes and the polynuclear aromatic fraction from process solvent and shale oil.

The results of skin carcinogenesis studies in the mouse (third level of tier testing) were generally consistent with those of the cellular studies. Heavy distillate, shale $0 i 1$ and the known carcinogen, benzo(a)pyrene, produced high incidences of skin tumors. Wilmington petroleum crude had less tumorigenic activity while LD has shown little tumor induction after 456 days of study.

Light distillate, MD, and HD were found to be moderately toxic after oral administration to rats (acute $L_{50}$ 's ranged from 2.3 to 3.8 grams/kilogram body weight). When the materials were administered once daily for 5 consecutive days, there were indications of cumulative effects. The effects of $L D, M D$, and $H D$ on development were determined 
after administration to pregnant rats from either 7-11 or 12-16 days of gestation (d.g.). Fetal growth and survival were decreased by LD, MD, or HD administration at either period. Administration of HD from 12-16 d.g. also increased the incidence of malformations (principally cleft palate, diaphragmatic hernia, and hypoplastic lungs). In most cases, doses of materials which produced prenatal toxicity also produced some indications of maternal toxicity.

Fuel upgrading, process modification, and appropriate occupational/ environmental controls may ameliorate some of the biological effects of SRC materials and other coal liquids of high boiling point. Low-boiling SRC liquids appear to have little biological effects in the assays employed. 


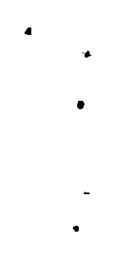




\section{BIOMEDICAL STUDIES ON SOLVENT REFINED COAL (SRC-II) \\ LIQUEFACTION MATERIALS: A STATUS REPORT}

\subsection{INTRODUCTION}

\section{Overview: DOE's SRC Environmental Program}

In parallel with the process development for the commercialization of economically viable coal conversion technology, DOE has established a program of investigation, assessment and control to insure the environmental acceptability of these processes. DOE's environmental program has been outlined generically for liquefaction processes in the Environmental Development Plan (DOE/EDP-0012, March 1978) and has been addressed programmatically for SRC-I and SRC-II in a Project Environmental Plan (PEP). The environmental program presented in the PEP is implemented jointly by Energy Technology (ET) and the Office of Environment (EV).

\section{PNL's Role in the Environmental Evaluation of SRC-II}

A number of organizations have been selected by DOE to evaluate the biomedical, environmental, and safety aspects of SRC-II. Pittsburg \& Midway Coal Mining Co. (P\&M) has been assigned responsibility for industrial toxicology. Oak Ridge Operations has been assigned responsibilit for the writing of necessary Environmental Impact Statements (EIS's) and the filing for EPA construction permits. Chevron, Cities Service, and 
Universal 0il Products Company have been assigned various responsibilities for investigation of process engineering strategies for upgrading coal liquefaction products.

In this context, PNL has been assigned responsibility for (1) generation of a biomedical and ecological data base for materials from the SRC processes, and (2) the development and application of appropriate protocols for the interpretation and use of these data for assessment of health and environmental impacts for the SRC processes.

Status of the PNL Program

PNL initiated biomedical and environmental studies with SRC materials in FY 1978 as part of an overall fossil fuel research effort. As an outgrowth of this research, PNL was requested to develop a comprehensive Program Plan for the evaluation of the health and ecological aspects of the SRC process. A preliminary Program Plan was prepared in the first quarter of 1979 for review by ET, EV, and P\&M staff. A revised comprehensive Program Plan has been drafted and is being submitted for DOE review and approval.

The present status report constitutes a technical presentation of the results of the PNL health effects research efforts which formed much of the basis for the Biomedical Research portion of the Program Plan. As such it constitutes the first in a series of regular status reports by PNL on SRC program activities, findings, and conclusions. Reports on PNL ecology and chemical monitoring/characterization will be completed within the near future. 
Outline of Present Status Report

PNL recognizes the critical role of representative sampling for health and ecological characterization. These samples should be chosen in a manner allowing extrapolation of the data obtained from pilot-plant, PDU, and bench-level materials to demonstration and commercial SRC materials. This concept defines 'scalable' for the purposes of this document. Accordingly, this and future reports will address two complementary issues: a) provenance of samples used in relation to pilot-plant operations; b) relationship of pilot-plant samples to potential demonstrational/commercial operations. This is followed by a comprehensive synopsis of PNL's experience and findings to date regarding the biological characteristics of SRC materials with particular emphasis on SRC-II materials. Finally, implications of findings to date are summarized. 
$\checkmark$

- 


\subsection{REPRESENTATIVENESS OF SRC-II \\ PILOT PLANT SAMPLES}

\section{Introduction}

Definitions of sample representativeness and development of adequate methodology for representative sample collection are sophisticated engineering issues that must be addressed in parallel with comparable issues in sample characterization. Sampling efforts for the collection of SRC-II materials used to date by PNL in its biomedical characterization effort preceded the development of sophisticated sampling protocols. While this fact did not pose a constraint to PNL's initial scoping objectives, application of well-defined sampling protocols in the future will be essential to assure extrapolation of results to demonstrationand commercial-scale materials.

What follows is a brief description of those unit operations in the SRC-II pilot plant and their corresponding operating practices which are relevant to process sampling. Key issues associated with representative oil sampling are then identified. With this information as back-

ground, the specific history of PNL's present SRC-II samples and the impact of this history on interpretations of the characterization results described later in this report are presented. 
Pilot-Plant Components and Operating Practices Relevant to Representative Sampling

Essential unit operations affecting SRC-II production and processing in the pilot plant at Fort Lewis, WA are outlined in Figure 1. Accompanying this is a listing of major operating practices which influence the characteristics of materials that might be collected for analysis. PNL samples were drawn from the raw product fractionation section of the plant.

When accurate yield data are required the pilot plant operates in a "material balance" mode. This mode is appropriate for sampling because stable equilibrium operation is normally achieved prior to entering this mode of operation.

Operation of high-pressure slurry pumps requires the continuous injection of a seal flush oil. In the pilot plant, SRC-II heavy distillate (HD) is used for this purpose. The flow rate of this material is high, typically two to three times that of fresh coal HD production. Raw SRC-II product is accumulated in tanks and is processed in a distillation unit on an intermittent basis during materials balance periods. Distillation conditions are set to accommodate smooth pilot-plant operation and produce desired distillation cuts.

Significant Issues Associated With Representative Sampling

Routine operations in the SRC-II pilot plant were established largely for the testing of equipment performance and the evaluation of 


\section{SRC-II PILOT PLANT CONFIGURATION}

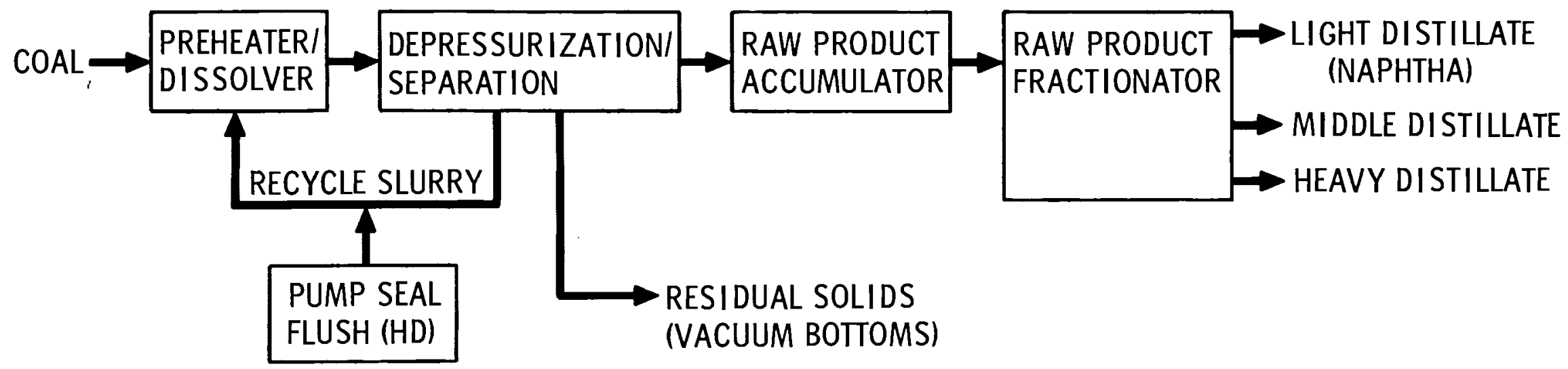

Significant Pilot Plant Operating Issues Affecting Plant 0 il Characteristics.

(1) At all times, pump seal flush introduces substantial amounts of previously produced

$H D$ into the recycle stream.

- During material balance periods, addition rate is $200-500 \mathrm{lb} / \mathrm{hr}$.

- During plant upset periods, a minimum of $200 \mathrm{lb} / \mathrm{hr}$ is introduced, even when coal feed to the dissolver is interrupted.

(2) The raw product accumulator is actually a complex, interconnected set of approximately 20 tanks, each of varying volumes.

(3) The raw product fractionation is a discontinuous operation carried out intermittently during and after material balance runs. Feed to this section may come from any of the 20 tanks comprising the product accumulator network.

Fiqure 1. Operating Practices Relevant to Representative SRC-II Pilot-Scale 0il Sampling. 
basic process characteristics. Acceptable (even desirable) operating practices in this context may not result in the production of representative material for biological studies. Five of the more significant plant operating characteristics which influence the representativeness of materials produced include:

(1) Source of Seal Flush HD. Unless carefully controlled, HD introduced for slurry pump seal flush is

- not necessarily balance period material;

- not necessarily from the current plant run;

- possibly produced from several runs involving different coals.

(2) Quantity of Seal Flush HD. The ratio of slurry pump seal flush HD to fresh coal HD production can be as high as $2.5: 1$, indicating that distilled HD product characteristics can be strongly influenced by the source of seal flush HD.

(3) Source of Distillation Feed. Unless deliberate special provisions are made, materials produced during plant startup, upset, and shutdown are piped to the same accumulator system as is balance period material. Slop and drip oils produced during material balance periods are often distilled with bulk materials.

(4) Events During Plant Upset. When a serious plant upset occurs, pump seal HD accumulates in the same tanks which hold raw material accumulated earlier during a balance period (unless special action is taken). 
(5) Assurance of Steady State. Minor shifts in oil composition may occur during a typical "material balance" period as a result of the relatively crude "measures" of plant approach to steady state.

Specific Processing History of PNL's SRC-II Samples

Heavy and middle distillate SRC-II samples were collected between 0400 and 0500 hours on January 29, 1978, while the pilot plant was processing Blacksville coal. A sample of light distillate taken at the same time was later found to be largely water. It was subsequently replaced with a light distillate sample collected at 0945 on February 8, 1978 while the plant was processing Illinois No. 6 coal.

Relevant details of plant operating history surrounding the times of plant sampling are summarized in Figure 2. Significant observations include:

(1) In neither sampling case had the pilot plant achieved fully stable operation before samples were collected.

(2) Feed to the distillation tower at the time of HD and MD sampling for PNL included:

- Fresh production from 2 days of balance period operation.

- Seal flush HD from blance period operation

- Seal flush HD during 30 hours of major plant upset

- Seal flush HD and fresh material production during approximately 30 hours of startup following plant upset.

No records exist which allow for an estimation of the distributions of these various material which might exist in PNL's samples. 
HEAVY AND MIDDLE DISTILLATE SAMPLES

Run 78SR-18

January 1978

Blacksville Coal

\begin{tabular}{lccc} 
& Period 1 & Period 2 & Period 3 \\
\hline $1800 h r$ & $1800 h r$ & $2300 h r$ & $0200 h r$ \\
$1 / 24 / 78$ & $1 / 26 / 78$ & $1 / 27 / 78$ & $1 / 31 / 78$ \\
\multicolumn{4}{c}{ Samples }
\end{tabular}

Period 1: Stable Operation

- $1800(1 / 24)$ to Balance Period, 78SR-18 $1800(1 / 26)$

Period 2: Upset

- $1800(1 / 26)$

Line plugging necessitated shutdown of coal feed.
Coal feed out for $30 \mathrm{hr}$; process solvent recirculation maintained.

\section{Period 3: Reactor Startup}

- $2300(1 / 27)$

- $1600(1 / 28)$

- $0430(1 / 29)$

- $0500(1 / 29)$
Coal feed increased from zero to 1 ton/hr: Composition of recirculating oil gradually changes.

Distillation of accumulated oil initiated.

Sample of middle distillate collected from distillation column (30 hr after initiation of coal feed).

Sample of heavy distillate collected from distillation column.
LIGHT DISTILLATE (NAPHTHA) SAMPLES

Run 78SR-19

February 1978

Illinois No. 6 Coal

\begin{tabular}{lll} 
& Period 1 & Period 2 \\
\hline $0200 \mathrm{hr}$ & $1200 \mathrm{hr}$ & $1200 \mathrm{hr}$ \\
$1 / 31 / 78$ & $2 / 9 / 78$ & $2 / 12 / 78$ \\
Sample
\end{tabular}

Period 1: Plant Startup

- $0200(1 / 31 / 78) \quad$ Switch from Blacksville to Illino is No. 6 coal.

- $0945(2 / 8 / 78) \quad$ Sample of naphtha collected from distillation column (199 hr into plant conversion from

Blacksville to Illinois No. 6 coal operation).

Period 2: Stable Operation

- $1200(2 / 9)$ to Balance Period, 78SR-19 $1200(2 / 12)$

Figure 2. Specific History of SRC-II Pilot-Plant Materials Used by PNL in its Biomedical Studies 
(3) Blacksville coal (source of HD and MD samples) is a relatively unreactive coal of low priority for commercial-scale SRC feed.

(4) At the time of light distillate sampling, the pilot plant had not completed its conversion of process materials from Blacksville to Illinois No. 6 coal.

Representativeness of PNL's Present Characterization Results

PNL samples were reasonably representative of a typical SRC-II pilot-plant mixed-coal 1 iquid inventory accrued during periods when operational parameters were being varied. As such, biomedical characterization results should be representative of the range of possible SRC-II pilot-plant material characteristics. The particular materials collected to date for PNL contain the probable spectrum of SRC-II components which are produced not only during stable operation, but also during plant startup and upset operations. 


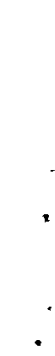




\subsection{RELATIONSHIP OF PILOT PLANT SRC-II}

\section{SAMPLES TO DEMONSTRATION PLANT MATERIALS}

\section{Introduction}

Ultimately, PNL's objective is to maximize the applicability of its sample characterization results to the evaluation of anticipated SRC-II demonstration-plant materials. This can be accomplished only by optimizing those technical relationships between anticipated demonstration-scale operations and current PDU and pilot-scale process operations. In its initial scoping exercise, PNL required only a generic relationship between its SRC-II samples and potential materials from a demonstrationscale facility. This was achieved.

Engineering issues involved in the definition of accurate scaling relationships are complex and to a significant degree dependent upon specific details of demonstration plant design--something which has been and continues to be in a state of flux. While this poses a challenge, it also represents an opportunity since experience gained in PNL characterization efforts can still significantly influence final demonstration plant design.

What follows is first a brief description of those SRC-II unit operations which most significantly influence the scaling of characterization data. Major issues associated with the projection of demonstrationscale oil characteristics are then outlined. With this information as background, specific circumstances surrounding PNL's current samples are reviewed and comments are made concerning their impact on the scaling of present results. 
SRC-II Unit Operations Affecting Scaling of Characterization Data

Significant unit operations presently anticipated for the demonstrationscale SRC-II plant in Morgantown, West Virginia, are summarized in Figure 3. With the exception of hydrodesulfurization operations, all of the listed unit operations have some form of counterpart in the SRC-II pilot plant in Fort Lewis, Washington.

Issues Associated With Projection of Demonstration-Scale Material Properties

The properties and fate of fresh material produced in the SRC-II preheater and dissolver depend to varying and largely unknown degrees on the design and operating characteristics of each of the unit operations cited above. Key issues and potentially important factors influencing the fate of materials during SRC processing are illustrated in Figure 3.

Particular Circumstances of PNL's Current SRC-II Samples

The following observations can be made regarding the relationship between anticipated demonstration-plant operations and pilot-plant practice at the time PNL's present SRC-II samples were collected.

(1) Feed coal type. Blacksville coal is a relatively low reactivity coal and is not expected to be used as a demonstration-plant feeds tock.

(2) Preheater/dissolver design and operating conditions. Major changes in mechanical design are possible for the demonstration plant. 


\section{PRESENTLY IDENTIFIED DEMONSTRATION PLANT CONFIGURATION}

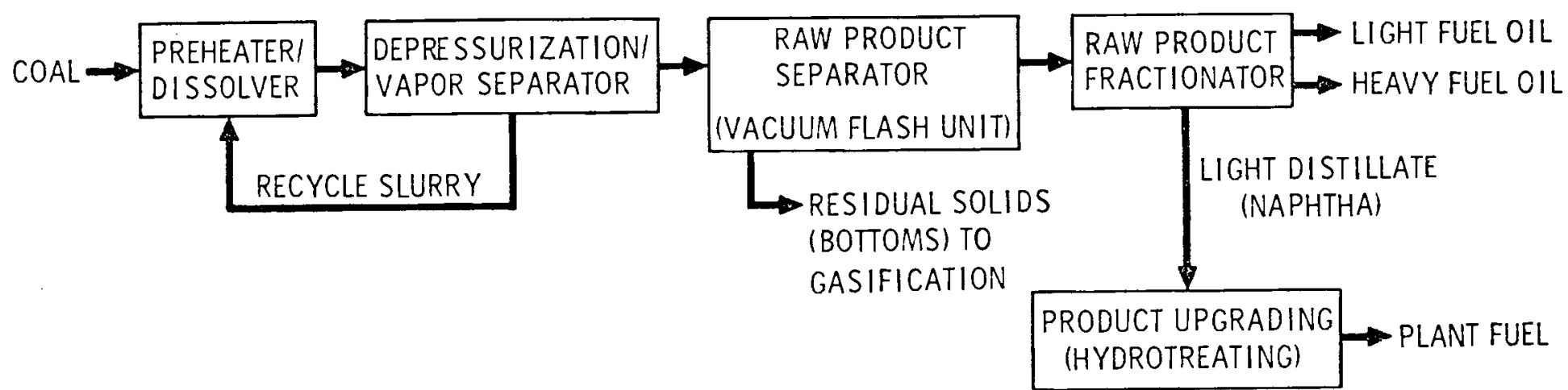

Important SRC-II Unit Operations for Pilot to Demonstration Plant Data Scaling:

PREHEATER/DISSOLVER

(1) Key Issue: Effect of varying operating parameters on biological characteristics of SRC materials

(2) Potential important process operating variables

- Coal type 1 - Temperature

(3) Relevant factors in vessel design

- Length/diameter - Internal flow characteristics VACUUM FLASH UNIT

(1) Key Issue: Partitioning of potentially biologically active hydrocarbons between the raw product and residual bottoms' streams

(2) Potentially important process operating variables

- Temperature

- Recycle ash concentration in feed slurry RAW PRODUCT SEPARATOR

(1) Key Issue: Relationship between variable prodict fractions and eventual demonstration product materials

(2) Potential important process operating variables

- Feed characteristics - Temperature (control)

- Efficiency (function of the number of trays) RAW PRODUCT UPGRADING

(1) Current Issue: Desulfurization for effective product utilitization as fuel

(2) Future Issue: Effect of upgrading on biological properties on SRC materials

Figure 3. Significant Factors Influencing Projections of Biological Characteristics for Demonstration-Scale SRC-II Materials from Pilot-Scale Data. 
Minor to significantly different operating conditions are anticipated. Product composition may be more strongly affected by changes in operating conditions than by design changes.

(3) Vacuum flash separator. Although detailed specifications of the raw product vacuum flash in the demonstration plant have not yet been finalized, they definitely will be more severe than those of the pilot-plant flash system. Directionally, fewer of the heavy components in SRC-II oil can be expected to remain with solid residues in the demonstration plant.

(4) Raw product fractionator. Product boiling point specifications for the demonstration plant are expected to change, at least to some degree, up to initiation of and during plant operation. Current pilot-plant fractionation provides only generic product breakdown to the light, medium, and heavy oil fractions which the present PNL samples reflect.

(5) Raw product upgrading. Pilot-plant products are not subjected to product upgrading. The PNL samples were not hydrodesulfurized.

Differences between pilot and demonstration plant design and operating procedures may influence the chemical and biological properties of SRC-II materials. One objective of the PNL program is to identify and address such influences. 
Current SRC-II samples are believed to encompass characteristics which may occur during one or more modes (startup, stable operation, upset, shutdown) of SRC-II demonstration plant operation. At this stage in program development, measured SRC-II sample characteristics cannot be assigned to any particular operating conditions or mode of plant operation and must be qualified as being the characteristics of a generic, unrefined SRC-II product. 



\subsection{SYNOPSIS OF BIOMEDICAL EXPERIENCE}

AND FINDINGS TO DATE

\section{Introduction}

The general objective of these studies is to provide biomedical information to aid in the timely development of the SRC technology. This objective is being approached by establishing a broad biomedical data base to: 1) identify areas of possible health effects problems; 2) assist the SRC technology to meet present and future regulatory requirements; and 3) help identify appropriate control technologies or plant operational parameters to minimize potential health effects problems.

The types of materials encountered in coal liquefaction processes are generally complex mixtures which may behave quite differently in biological systems than do individual constituents when studied alone and in a pure form. Interactions among constituents may result in both antagonistic and synergistic effects, the sum of which may or may not be predicted from the individual materials. Our philosophy, therefore, is to chemically characterize SRC materials (raw products, process stream materials, solid wastes, etc.) which are important in considerations of health and environmental consequences of production, storage, transport, accidental spills, and maintenance. We then characterize these mixtures biologically, using cellular and animal systems, and relate biological activity to chemical composition. Further identification of the components producing biological activity is performed through iterative cycles consisting of chemical and physical fractionation accompanied by bioassay of the fractions obtained. 
We have selected SRC materials for biological evaluation using the following criteria: 1) quantities of materials produced; 2) likelihood of exposure of occupational or general populations; 3 ) route of possible human exposure; and 4) ability to obtain samples representative of or meaningful to commercial practice.

The program that we have designed is aimed at providing information in the following areas:

1. Identification of possible sources of toxic and carcinogenic materials

2. Chemical characterization of major products and effluents

3. Effects of these materials and their subfractions on microbial and mammalian cells

4. Acute and subchronic toxicologic studies including teratogenesis and pulmonary function with selected materials after dermal, inhalation and oral exposure in animals

5. Long-term effects, including carcinogenesis of selected materials and their subfractions in animals

6. Studies of the biologic fate of selected materials and the effects of these substances on biotransformation and detoxification systems in rodents.

We have approached the study of these materials in two concomitant modes. In the first mode we have used chemical characterization and plant operational data to select materials to be evaluated using a tier approach. In this mode, materials are first assayed using microbial 
systems. On the basis of the results of the microbial assays, materials are selected for study in mammalian cell culture. Results generated in the cellular systems are used as selection criteria for materials to be used in animal assays. In the second mode, materials considered to be of prime importance to occupational or environmental health are entered directly into animal systems for study of acute, subchronic, and developmental toxicity. Long-term effects studies are then designed using the results of these studies, the cellular assays, and the chemical characterization data. At each level of testing, we have included other materials for comparative purposes. These materials, which include shale oil, petroleum crudes, other fossil-derived materials and pure known chemical mutagens and carcinogens, help us in placing results with SRC materials in a more meaningful perspective. It should be noted, however, that the SRC-II materials are distillate fractions whereas the shale oil and petroleum are full boiling range crudes.

We have in our program attempted to establish a balance between standardized biological testing and research. The use of standard testing protocols permits us to obtain information necessary for the evaluation of the potential health hazards of a number of important materials in order to meet regulatory demands. Research enables us to obtain a broader understanding of the nature of potentially harmful materials as well as to obtain data which will permit a better extrapolation of the experimental data to man. The research effort also allows us to explore potential ways of ameliorating the adverse effects of such materials.

In the following sections, the results of a number of biological studies with SRC and other materials are summarized. These include 
studies of: (1) microbial mutagenesis/chemical characterization, (2) in vitro mammalian cell toxicity and transformation, (3) epidermal carcinogenes is (skin painting), (4) acute and subchronic oral toxicity, (5) developmental toxicity, and (6) dosimetry and metabolism.

Microbial Mutagenesis/Chemical Characterization (For greater detail, see Appendix A.)

The use of cellular systems, both microbial and mammalian cell cultures, permits the study of a large number of materials at a relatively low cost. The most commonly used cellular assay is the Ames Salmonella mutagenesis assay. This assay is currently being used extensively because of its ease of usage, speed, low cost, requirement of small amounts of test materials and high correlation with carcinogenicity in the case of pure compounds. At this time a number of SRC materials as well as other materials used for comparative purposes have been assayed by standard methods or by modifications which optimize the mutagenic evaluation of complex chemical mixtures. Materials found to be active in the Ames system have been fractionated by chemical and physical means in order to determine which components are responsible for mutagenic activity.

Briefly, the Ames assay is performed by mixing the test material with the organism in the presence or absence of mammalian liver microsomal enzymes (59) and determining the number of organisms which revert (mutate) from dependency on histidine in the medium to nondependency. Assay in the presence of $\mathrm{S} 9$ detects mutagens which require metabolic activation to effect mutagenesis; assay in the absence of 59 detects mutagens which do 
not require metabolic activation. Use of appropriate strains of Salmonella permits determination of the nature of the mutation (frame shift or point mutation) which is a function of the biochemical properties of the test materials.

Examples of the data obtained with a number of crude materials are shown in abbreviated form in Table 1. It can be seen that of the three major process stream materials from the SRC-II process, the heavy distillate (high-boiling-point material) is the most active mutagenically. The light and middle distillates showed no mutagenic activity. The known chemical carcinogen, benzo(a)pyrene (BaP), shows approximately $3 x$ the activity of heavy distillate (HD) while another well-known chemical carcinogen, 2-aminoanthracene (2-AA), is about 100 times as active. Raw shale oil shows a small degree of activity while crude petroleum showed no activity in the Ames system.

The HD was fractionated using a solvent extraction procedure. In addition to yielding the expected acidic, basic, and neutral fractions, fractionation of HD also yielded basic and neutral tar fractions. When these fractions were assayed using the Ames system, the highest specific activity (number of revertants per microgram of material) was found in the basic fraction. Significant activity was also found in the basic and neutral tar fractions, although the specific activity was about 1/8 - 1/2 that of the basic fraction. The total mutagenic activity in the basic and neutral tar fractions, however, was greater than that in the basic fraction due to the substantially greater mass of the tars. The acidic and neutral fractions showed essentially no mutagenic activity. Examination of fractions from shale oils and other materials also showed that the basic fraction contained the highest specific activity. 
Table 1. Comparison of the Mutagenicity of Solvent Refined Coal Materials, Shale 0ils, and Crude Petroleums in Salmonella Typhimurium TA98

Materials

SRC-I I

Heavy distillate

Middle distillate

Light distillate

SRC-I

Process solvent Wash solvent

Light 0 il

Shale $0 i 1$

Paraho-16

Paraho-504

Livermore LOT

Crude Petroleum

Prudhoe Bay

Wilmington

Pure Carcinogens

Benzo(a)pyrene

2-Aminoanthracene
Revertants/ $\mu \mathrm{g}$ of Material
$12.3+1.9$

$<0.01$

$<0.01$

$0.60+0.19$

$0.59 \mp 0.13$

$0.65 \mp 0.22$

$<0.01$

$<0.01$

$114+5$

$5430 \nsubseteq 394$ 
The above results led to further studies of the nature of mutagenic materials present in HD. It was felt on the basis of previous chemical analyses that polar nitrogen-containing compounds might be responsible. To test this idea the SRC-II distillates and their basic and tar fractions were analyzed by thin layer chromatography (TLC) using a solvent system designed to separate the polar nitrogen-containing compounds from lesspolar constituents. Samples of pure chemicals were also chromatographed to aid in the location and identification of major compound classes known or suspected to be present in HD. Fluorescent areas corresponding to these chemicals were located by illumination with an ultraviolet 1ight. The chromatograms were cut into strips, the strips extracted with a hexane-acetone mixture, and the extracts subjected to study for mutagenic activity.

The separation of the mutagenic contituents from HD is depicted schematically in Figure 4. The major portion of the activity was found to migrate with $\mathrm{Rf}$ values (distance migrated by the test material/distance traveled by the solvent front on a TLC plate) between 0.07 and 0.20 . These values are very close to those obtained for aromatic amines, a class of compounds suspected but not previously shown to be present in SRC-II materials. Similar results were obtained when the basic tar or neutral tar fraction of HD (or SRC-I process solvent [PS] and PS basic and tar fractions) were chromatographed.

Extracts from the mutagenically active regions after thin layer chromatography of heavy distillate and its fractions were subjected to gas chromatographic/mass spectral (GCMS) analysis to identify specific components. Several primary aromatic amines, including aminonaphthalenes (AN), aminoanthracenes (AA), aminophenanthrene (APH), aminopyrenes (AP) 
BASIC II

\section{SOLVENT}
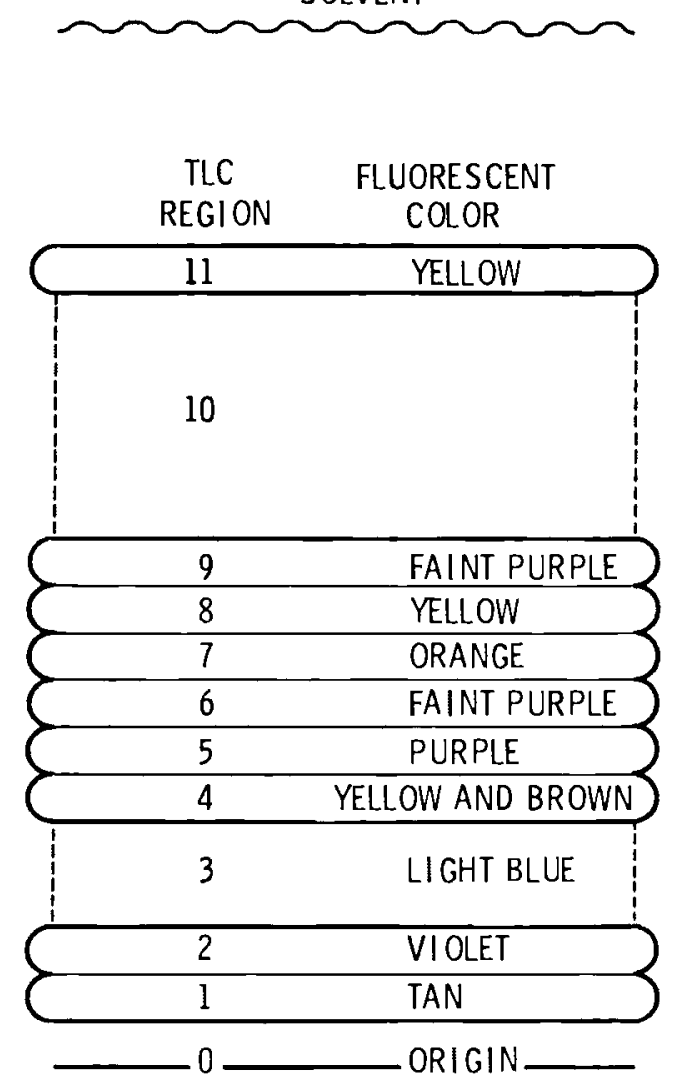

Figure 4. Ames Mutagenicity Analysis of Materials Eluted from Thin Layer Chromatogram of the Basic Fraction of SRC-II Heavy Distillate. 
and aminochrysenes $(A C)$, were found to be associated with TLC regions which were mutagenically active. An estimate of the aromatic amine content of the active TLC regions from the HD basic fraction is shown in Figure 5; the relative concentrations of $A A, A P, A P H$ and $A C$ were highest in the regions with the strongest mutagenic activity. With the exception of AN, primary aromatic amines were not found in regions that lacked mutagenic activity. Aminofluorenes (AF) and aminocarbazoles were tentatively identified in active regions from the basic fraction but higherresolution analysis must be performed to obtain more definite identification. Qualitatively similar results were obtained when the basic or neutral tar fractions were analyzed. Analyses of these materials suggest that the 3- and 4-ring primary amines are important mutagens but that the 2-ring aminonaphthalenes contribute little to mutagenic activity.

Since GCMS analysis showed the presence of aromatic amines in the mutagenically active regions of thin layer chromatograms of the basic, basic tar and neutral tar fractions of $H D$, a series of experiments were performed to determine if these amines were responsible for the mutagenic activity. One approach utilized the unique catalytic properties of a purified liver enzyme system called mixed-function amine oxidase (MFAO). This enzyme is specific for the metabolic transformation of primary aromatic amines to a mutagenically active state as shown in Figure 6. The MFAO is inactive with BaP and other polycyclic aromatic hydrocarbons (PAH). Nor does it activate the 2-aminonaphthalenes, probably due to the instability of the enzyme product. Previous experiments utilized a mixture of hepatic enzymes (called S9) which activate a wide variety of PAHs; therefore, no distinction could be made between amines and 

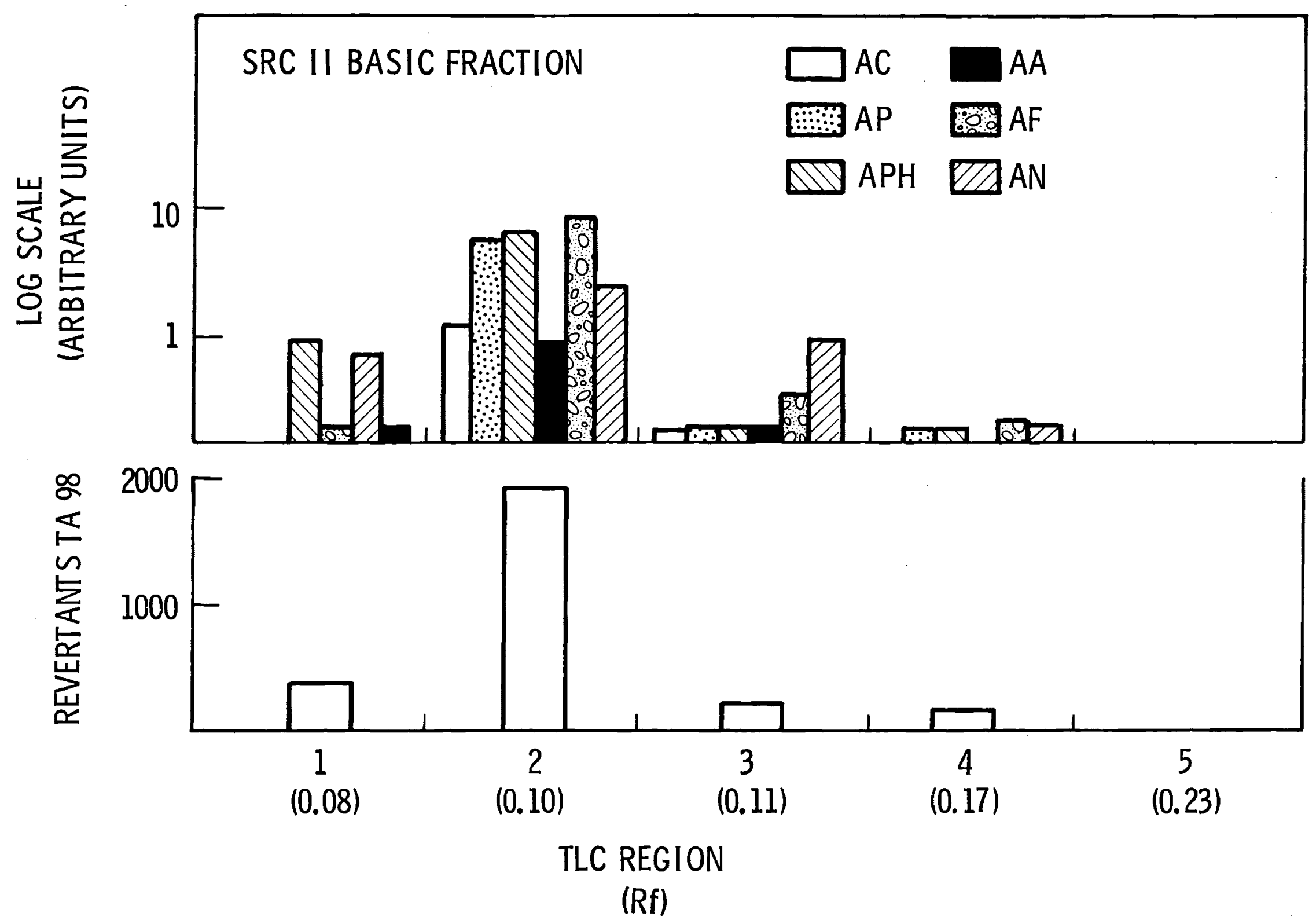

Figure 5. Relative Concentrations of Aromatic Amines and Mutagenic Activity in Regions 1-5 of Thin Layer Chromatograms of the Basic Fraction of SRC-II Heavy Distillate. 


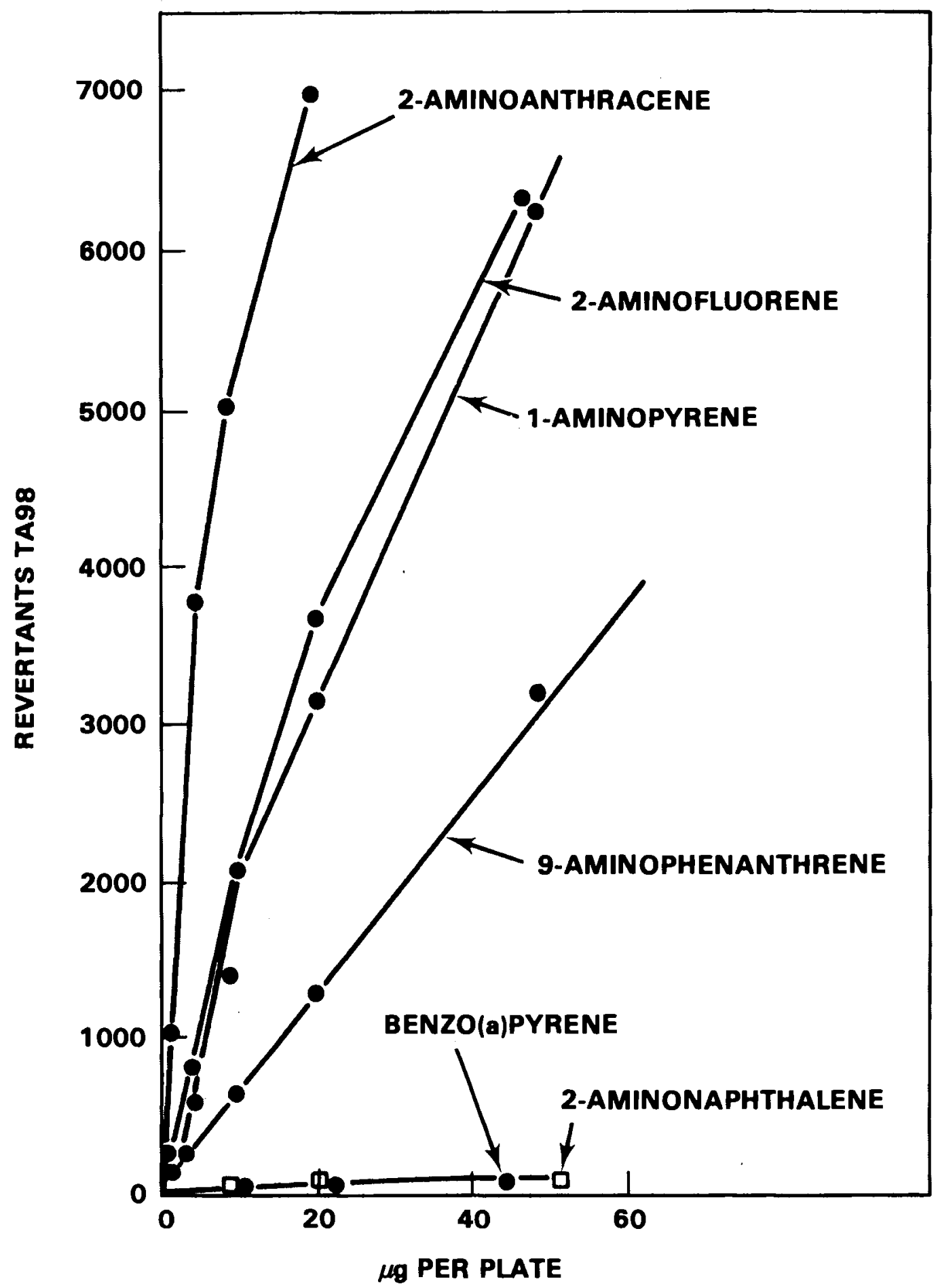

Figure 6. Dose Response of S. typhimurium TA98 to Several Aromatic Amines and Benzo( $\bar{a})$ pyrene Using the Mixed-Function Amine Oxidase for Metabolic Activation. Each assay plate contained $2.5 \times 10^{8}$ cells and 10.6 units of the amine oxidase. 
other polycyclic constituents. In this set of experiments, HD and its basic, basic tar and neutral tar fractions were again subjected to thin layer chromatography and the various regions tested for mutagenic activity after activation with either MFAO or S9. Again, TLC regions with $R_{f}^{\prime} s$ of approximately 0.08 to 0.20 were found to contain the major portion of the activity when the assay was performed using 59 , as had been seen previously. When activation was performed using MFAO, the same distribution of mutagenic activity among the TLC regions was found as with S9 (Figure 4). These results thus provide direct evidence that aromatic amines are both present and capable of expressing their mutagenic activity in HD and its basic, basic tar, and neutral tar fractions.

The second approach to examine the question of whether the aromatic amines are responsible for mutagenic activity was to nitrosate the amine group by treatment with nitrous acid. Nitrosation reduces the mutagenicity of aromatic amines but not that of other polycyclic compounds. When HD, its basic, tar fractions, or PS and its basic and tar fractions were treated in this manner, the mutagenic activity fell markedly, by at least 90 percent (Figure 7 ). The nitrosation data thus provide evidence that aromatic amines are the major source of activity in the Ames assay.

\section{Mammalian Cell Culture Studies}

(For greater detail, see Appendix B.)

The SRC-II materials studied in the Ames assay were then entered into toxicity and transformation assays using cultured mammalian cells. These studies represent the next higher level of testing in the tier approach. 


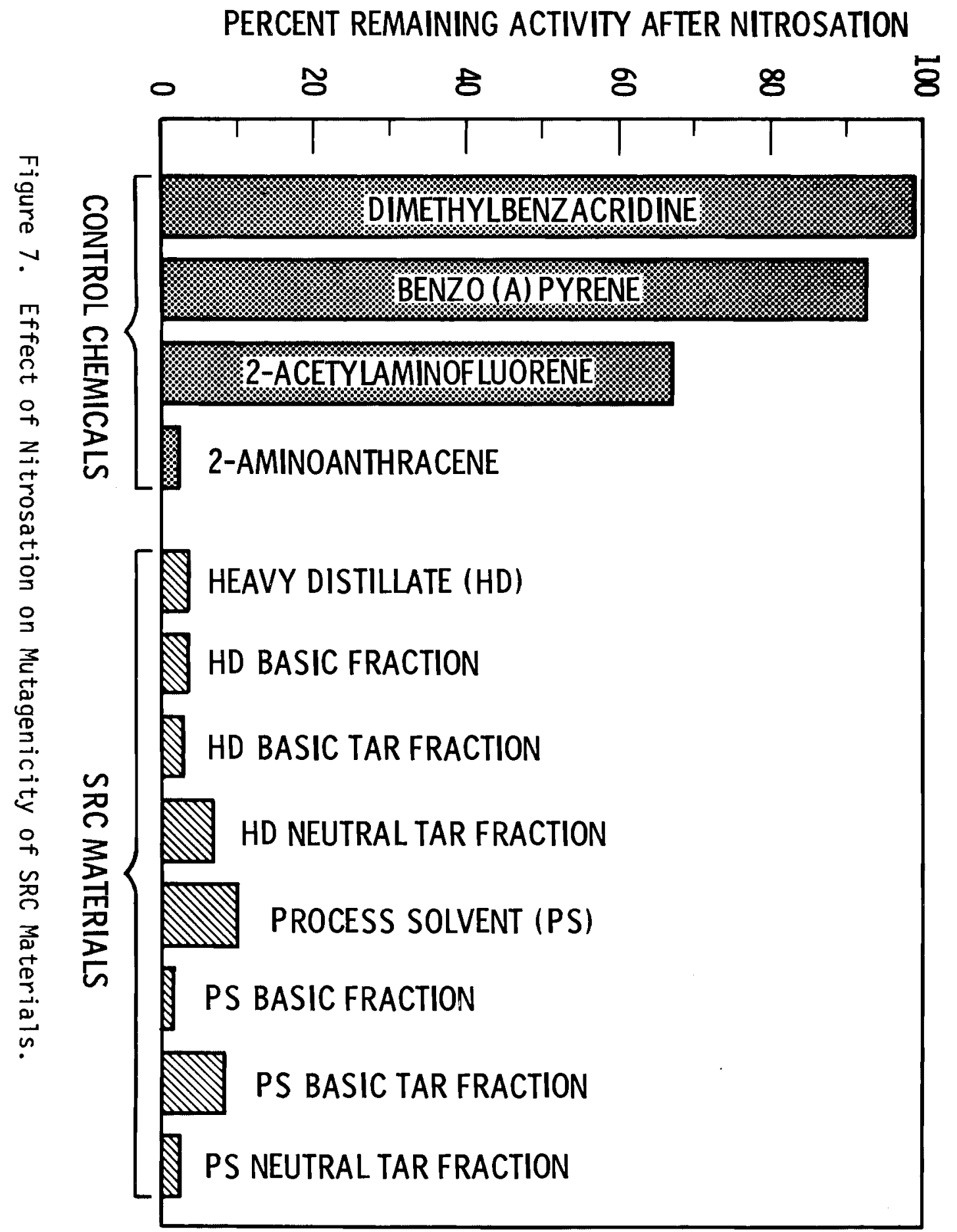


The VERO cell line which is derived from monkey kidney cells was used for cytotoxicity testing because it is well-characterized, stable and has been used for a number of other studies in our laboratory. In this assay, monolayered cultures of cells are treated with trypsin to obtain monodispersed cells. Known numbers of cells are treated with dilutions of the test material in small wells in a test plate. They are then incubated under standardized conditions for 4 days and the number of clones (colonies of 10 or more cells) are determined. The ratio of number of clones produced by treated cells to number produced in the controls is referred to as the relative plating efficiency (RPE). The $\mathrm{RPE}_{50}$ (the dose of test material producing a $50 \%$ reduction in RPE) may be used to compare the relative toxicities of different materials.

The toxicities of SRC-II light, middle and heavy distillates are compared with those of SRC-I light oil (LO), wash solvent (WS), and process solvent (PS), shale oil (SO), Wilmington and Prudhoe Bay crude petroleums, diesel oil \#2 and cadmium in Table 2. Of the fossil-derived materials, HD, PS and SO were found to be the most toxic, with $R E_{50}$ 's of $30-50 \mu \mathrm{g} / \mathrm{ml}$; the $\mathrm{RPE}_{50}$ 's of the other materials were in excess of $150 \mu \mathrm{g} / \mathrm{ml}$. Cadmium toxicity, however, was about $100 x$ greater $(0.3 \mu \mathrm{g} / \mathrm{ml})$ than that of HD, PS and SO. Under certain conditions, mammalian cells treated in vitro with known carcinogens may undergo morphologic and biochemical changes (transformation) which result in unrestricted growth, analogous to that of cancer cells. Transformation assays are therefore used as relatively rapid and inexpensive tests for screening materials for potential carcinogenicity. 
Table 2. Cytotoxicity of Fossil Fuel Materials and Metals in Cultured Vero Cells

Material

$\mathrm{RPE}_{50}$ Dose $(\mu \mathrm{g} / \mathrm{ml})^{\mathrm{a}}$

SRC-II

Heavy distillate

30

Middle distillate

200

Light distillate

180

SRC-I

Process solvent

PNA fraction

Basic fraction

Neutral fraction

35

30

100

75

Shale 0il (S-11)

50

PNA fraction

40

Basic fraction

50

Neutral fraction

200

Petroleum

Prudhoe Bay crude

Wilmington crude

190

Diesel oil \#2

250

Metals

Cadmium chloride

Zinc chloride

0.3

Lead chloride

6.8

37

\footnotetext{
$\mathrm{a}_{\mathrm{RPE}} \mathrm{F}^{50}=$ dose required to reduce number of colony-producing cells to $50 \%$ of control value.
} 
We have used Syrian hamster embryo (SHE) cells to study the ability of SRC materials to effect transformation. In this assay, cells are preincubated in Petri dishes for 16-24 hours and then treated with the test material, either with or without 59 , to provide metabolic activation. After 21 days, the cells are fixed and stained and the number of transformed colonies as well as the total number of colonies are counted. Heavy distillate, PS, SO, the basic fraction of SO, and Prudhoe Bay and Wilmington petroleum crudes along with the basic and PNA fractions of process solvent were assayed for transforming activity (Table 3). Heavy distillate, PS and BaP produced a higher percentage (7-11\%) of transformed colonies than did the petroleum crudes $(0.2-0.4 \%)$, so $(3 \%)$ or the PNA fractions of PS (2\%) or SO (3.4\%). However, the basic fractions of both PS and SO had higher activities than did HD or PS. For all materials, the transformation frequency was higher with 59 than without. Heavy distillate, PS, and the basic fractions of PS and SO, however, produced a low frequency of transformation even without 59 . These data show that a number of fossil fuel-derived materials are capable of transforming SHE cells in culture. Selected colonies of PStransformed cells were grown through 20 passages in culture and $5 \times 10^{6}$ cells from each line were injected subcutaneously into nude mice, which have a relatively high immunologic tolerance. All cell lines produced undifferentiated sarcomas at the site of inoculation. The growth of PS-transformed cells in nude mice suggests that these cells have become neoplastic. 
Table 3. Effect of Solvent Refined Coal Materials, Shale 0il and Petroleum Crudes on Cloning Efficiency and Transformation Frequency in Syrian Hamster Embryo Cells

Material

Dimethyl sulfoxide

Heavy distillate (SRC-II)

Process solvent (SRC-I)

Basic fraction

PNA fraction

Shale oil $(L E R C)^{a}$

Basic fraction

PNA fraction

Prudhoe Bay crude

Wilmington crude

Benzo(a)pyrene

a Laramie Energy Research Center

$$
\begin{array}{lcr}
\text { Concentration }(\mu \mathrm{g} / \mathrm{ml}) & \% \text { of } & \text { Relative } \\
\text { to produce maximum } & \text { colonies } & \text { cloning }
\end{array}
$$
transformation frequency transformed efficiency

$(\%)$

$\begin{array}{rrr}0 & 0 & 100 \\ 20 & 6.8 & 33 \\ 100 & 10.0 & 31 \\ 50 & 22.0 & 36 \\ 5 & 2.0 & 95 \\ 10 & 2.7 & 34 \\ 10 & 8.9 & 77 \\ 50 & 3.4 & 74 \\ 200 & 0.4 & 23 \\ 100 & 0.2 & 48 \\ 20 & 11.0 & 42\end{array}$




\section{Epidermal Carcinogenesis}

(For greater detail, see Appendix C.)

The data generated in the first two stages of our tier-testing approach, the microbial mutagenesis and mammalian cell studies, suggested a number of materials for further testing in animals for possible carcinogenicity. Since animal studies are time-consuming and expensive, a limited number of materials were chosen for evaluation of carcinogenesis using the mouse skin-painting system. Of the SRC materials, HD was selected because it was mutagenically active in the Ames system and because results in the literature showed other high-boiling-point coal liquids to be carcinogenic; LD was selected because it was not mutagenic. We felt that we could better evaluate the correlation between the cellular assays of complex mixtures and carcinogenesis if we used both mutagenically active and inactive materials. For comparative purposes, we also included crude shale $0 i l$ and Wilmington crude petroleum as representatives of other fossil-derived materials, and $\mathrm{BaP}$ and 2-AA as representatives of two different classes (polynuclear aromatic hydrocarbons and aromatic amines) of known chemical carcinogens. Mice (strain $\mathrm{C} 3 \mathrm{Hf} / \mathrm{HeBd}$ ) of both sexes were obtained from the Biology Division of Oak Ridge National Laboratory (through the cooperation of Dr. J. M. Holland). This strain is being used at both ORNL and Los Alamos Scientific Laboratories for analogous studies, thus allowing comparison of results from the three laboratories. The dorsal surface of each mouse, from the neck approximately halfway to the tail, was shaved prior to the first application and thereafter as required. Fifty microliters of the test material in 
acetone were applied to the shaved area three times per week. The doses selected for the long-term study were based on the results of an acute study, which consisted of the daily application of a concentrated solution of each material in acetone $5 X$ a week for 2 weeks. The highest concentration of each material that produced no weight loss or other clinical sign of systemic illness was selected as the highest dose for the longterm study. Two other doses, representing $1 / 10$ and $1 / 100$ of the highest dose, were also used, thus providing nominal low, medium, and high dose groups (see Table I, Appendix C for amounts of each material used). Untreated and vehicle-treated (acetone) controls were also included.

The data in Table 4 summarize the results of this study at 456 days after initiation. Most of the numbers are based on gross observation; however, of the tumors examined microscopically, the histopathologic diagnoses have agreed with gross observations in $98 \%$ of the cases. Except for the two control groups, tumors of the skin have appeared in mice exposed to each of the materials. The two highest dose groups of $\mathrm{HD}, \mathrm{BaP}$ and SO either have reached or are approaching $100 \%$ incidence. of the lowest dose groups for the various materials, only HD-treated mice have tumors at this time. The incidences for the medium and high dose groups which received Wilmington crude petroleum are 7 and $42 \%$, respectively. In contrast, only one mouse in each of the medium and high dose groups exposed to LD has developed a skin tumor. Although an acute study of toxicity was performed with 2-AA, longer exposure at the $0.5 \mathrm{mg} / \mathrm{application}$ dose resulted in high mortality; thus, only two groups (0.05 and $0.005 \mathrm{mg} / \mathrm{application)}$ remain. The higher of these two groups has an incidence of $78 \%$ while the incidence to date in the lower group is zero. 
Table 4. Skin Tumor Incidence in Mice at 456 Days of Exposure to Fossil Fuel Materials or known Carcinogens.

\begin{tabular}{|c|c|c|c|c|c|}
\hline Treatment & $\begin{array}{c}\text { Dose } \\
\text { (mg/application) }\end{array}$ & $\begin{array}{c}\text { Tumor } \\
\text { Incidence } \mathrm{a} \\
\end{array}$ & $\begin{array}{l}\text { Minimum } \\
\text { Latency (days) }\end{array}$ & $\begin{array}{c}\text { Median } \\
\text { Latency (days) }\end{array}$ & $\begin{array}{c}\text { Maximum } \\
\text { Latency (days) }\end{array}$ \\
\hline
\end{tabular}

\begin{tabular}{|c|c|}
\hline $\begin{array}{l}\text { Control - Untreated } \\
\text { Vehicle control (acetone) } \\
\text { Heavy distillate } \\
\text { SRC-II }\end{array}$ & $\begin{array}{r}-.- \\
-22.8 \\
2.3 \\
0.23\end{array}$ \\
\hline $\begin{array}{l}\text { Light distillate } \\
\text { SRC-I I }\end{array}$ & $\begin{array}{r}20.0 \\
2.0 \\
0.2\end{array}$ \\
\hline Shale $0 i 1$ & $\begin{array}{r}21.2 \\
2.1 \\
0.21\end{array}$ \\
\hline $\begin{array}{c}\text { Crude Petroleum- } \\
\text { Wilmington }\end{array}$ & $\begin{array}{r}16.8 \\
1.7 \\
0.17\end{array}$ \\
\hline Benzo(a)pyrene & $\begin{array}{l}0.05 \\
0.005 \\
0.0005\end{array}$ \\
\hline 2- Aminoanthracene & $\begin{array}{l}0.05 \\
0.005\end{array}$ \\
\hline
\end{tabular}

$0 / 49$
$0 / 47$
$49 / 49$
$47 / 47$
$6 / 48$

$1 / 44$
$1 / 46$
$0 / 41$

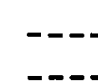

$38 / 38$

$41 / 50$

$0 / 45$

$20 / 45$

$3 / 45$

$0 / 46$

$50 / 50$

$44 / 46$

$0 / 50$

$25 / 32$

$0 / 49$
56

72

282

410

427

$----$

95

294

-.-

---

$---$

213

351

148

148

260

282

$----$

106

232

$----$

115

-.-.

379

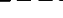

147

372

$---$

---

-

409

-----

---

$-1$

193

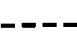

Days to $50 \%$ tumor incidence

CDays to $100 \%$ tumor incidence 
The latent period for tumors was shortest in mice exposed to HD. The first tumors in the high and medium dose groups of HD-exposed mice appeared at 56 and 76 days, respectively. The median tumor latencies (time at which $50 \%$ of the group had tumors) in these groups were 95 and 294 days, respectively. The first tumors were observed in the high dose groups of $\mathrm{BaP}$ and SO at 106 and 95 days, with a $50 \%$ incidence at 213 and 143 days, respectively. The median time of tumor appearance for the other groups was generally greater than 300 days.

The vast majority of tumors which have been examined histologically are malignant, regardless of treatment group. Most tumors contain areas of well-differentiated squamous cell carcinoma as well as areas of spindle cell morphology. The cell of origin for this latter tumor type is not apparent at this time but future electron microscopic and transplantation studies may aid in providing an answer.

\section{Discussion of Microbial Mutagenesis, Cell Culture and Epidermal}

\section{Carcinogenesis Studies}

The microbial and cell culture studies showed that $\mathrm{HD}, \mathrm{SO}, \mathrm{BaP}$, and 2-AA are capable of causing mutational changes in both microbial and mammalian cells. Information in the literature has suggested that these effects in cellular systems may be correlated with carcinogenesis in animals. Study of the above materials, as well as of LD which was not active in the cellular systems, would appear to be consistent with the suggested correlation between cellular and animal studies; HD, SO, BaP and 2-AA readily induced tumors while the tumorigenic activity of LD was 
extremely low. However, there are both qualitative and quantitative differences in the results of the cellular and animal studies. Quantitative differences between measures of tumorigenicity and mutagenicity or cellular transformation may be seen for BaP, 2-AA, HD and SO. Heavy distillate had about a quarter of the mutagenic activity of BaP and about $1 / 100$ that of 2-AA. Yet it induced skin tumors much earlier than either BaP or 2-AA. The mutagenic activity of shale oil was even lower than that for HD but the tumor latency was shorter than that for 2-AA and not vastly different than for BaP. If the actual amount of material applied to the skin is used as a basis for comparison, a different view is obtained. The total amount of BaP used to produce a comparable tumor incidence is $300-400$ times less than that of $H D$, whereas at least two to three times more 2-AA than $\mathrm{BaP}$ is required to produce a comparable tumor incidence, even though 2-AA is 20-30 times more active mutagenically. However, comparisons based solely on the total amount of a crude mixture (e.g., HD) applied must be viewed cautiously since the known or candidatecarcinogen components comprise a small proportion of the total mixture.

The results of the tranformation assays are in general agreement with those from the Ames assays. Heavy distillate, PS and SO possess significant activity in both assays while the basic fractions are even more active than the unfractionated crudes. Unlike the Ames assay, the transformation assay responded to the PNA fraction of PS and SO, although the response was less than for the basic fractions. A low degree of activity was also found with the crude petroleums which were not active in the Ames system.

If the skin tumor data are evaluated in light of the mammalian cell transformation data, the qualitative agreement is even better than with 
the microbial mutagenesis data. This is not unexpected since the mammalian cell assays are regarded as a progressive step in the tier approach. It should be noted, however, that many of the quantitative differences between dermal carcinogenesis and microbial mutagenesis also exist between dermal carcinogenesis and mammalian cell transformation. Certainly, differences in rates of absorption as well as in the metabolism of the different materials in the animal may influence both the latency and incidence of tumors. If the BaP content of $H D$ is examined, it can be seen that it is not sufficient to account for the carcinogenicity of HD, especially when latency is used as a basis for comparison. The same would appear to be true for other individual PAH's and aromatic amines. The carcinogenicity may thus be a result of the combined action of a number of compounds in this complex mixture.

The qualitative disparity lies in the failure of the microbial system to predict Wilmington crude petroleum to be tumorigenic. This apparent disparity may, however, also be quantitative since fractionation of crude petroleums has been found to provide materials with sufficient concentrations of mutagens to yield positive results in the Ames assay. Thus, many questions remain to be answered to improve the reliability of cellular screening tests as predictors of carcinogenicity as well as to develop the relationships between mutagenesis and carcinogenesis. As results from several levels of testing become available for more materials, we should be better able to address these issues. 
Acute and Subchronic Oral Toxicity

(For greater detail, see Appendix D.)

The toxicities of SRC-I LO, WS, PS, and SRC-II LD, MD, HD, have been compared to those for So, petroleum crudes, and diesel oil (D0) after oral administration. These studies were performed to provide estimates of the limits of tolerance for these materials and to guide the selection of doses to be used in studies of developmental toxicity. The test material was administered either undiluted or diluted in corn oil by stomach tube to adult Wistar rats which had been fasted overnight. Animals were observed closely for 3 days following administration of the test material for clinical symptoms of toxicity. Weights were taken before and for 2 weeks following dosing. Process solvent and HD have also been studied in immature 14- and 21-day old rats to determine if the younger animal is more sensitive.

The relative toxicities of the materials expressed as the dose $(\mathrm{g} / \mathrm{kg}$ body weight) required to kill $50 \%$ of the animals in 3 days are shown in Table 5. Wash solvent was clearly the most toxic of the materials that we examined $\left(L D_{50}=0.57 \mathrm{~g} / \mathrm{kg}\right)$. The $L D_{50}$ values of $L D, P S, L O, H D$, and MD formed a group ranging from 2.3-3.8 $\mathrm{g} / \mathrm{kg}$ while the values for SO, DO, and crude petroleum were in excess of $9.0 \mathrm{~g} / \mathrm{kg}$.

Fourteen-day-old rats were significantly more sensitive to PS $\left(L_{50}=1.74 \mathrm{~g} / \mathrm{kg}\right)$ and $\mathrm{HD}\left(\mathrm{LD}_{50}=1.41 \mathrm{~g} / \mathrm{kg}\right)$ than were the adults. Weanlings were only slightly more sensitive than the adults.

Subchronic toxicity was determined for LO, WS, PS, LD, MD and HD by administering the material to fasted female Wistar rats by gavage once daily for 5 consecutive days. Deaths, weight changes and clinical symptoms of toxicity were monitored as in the acute studies. 
Table 5. Comparison of the Acute and Subchronic Toxicities of SRC Materials in the Female Wistar Rat ${ }^{a}$

\section{Material}

Wash solvent

Light distillate

Process solvent

Light $0 i 1$

Heavy distillate

Middle distillate

Shale oil

Diesel oil

Crude petroleum

$$
\text { Acute } b
$$$$
\underline{L D_{50}}
$$

$$
0.57(1.66)^{C}
$$

2.30

2.81

2.90

2.98

3.75

9.22

11.8

$>12$

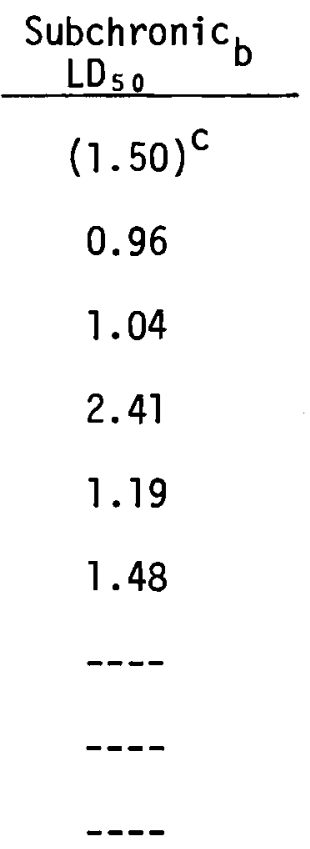

a The materials were administered one time by gavage for the acute toxicity studies. For the subchronic studies, materials were gavaged once daily for five consecutive days.

$\mathrm{b} \mathrm{LD}_{50}$ is defined as the dose in grams per kilogram of body weight required to $k i l l$ 50\% of the animals. For the acute toxicity study, this value represents a single dose while for the subchronic studies, the value represents a daily dose.

${ }^{C}$ The $L_{50}$ values in parentheses are for materials diluted in corn $0 i 1$. Al1 other values are for undiluted material. 
The subchronic $L D_{50}$ values for $L O$ and WS were not greatly different than those from the acute studies (Table 5). The subchronic values for all of the other materials were substantially lower than the acute values. These data indicate that the cumulative effects of $L O$ and WS are rather low but that for $P S, L D, M D$ and $H D$, either the material or the effects are cumulative.

Developmental Toxicity

(For greater detail, see Appendix E.)

Since the prenatal individual is significantly more sensitive to a number of toxic agents than are adults, studies have been performed to determine the effects of SRC materials administered during pregnancy in rats. The study materials were administered once daily for 5 consecutive days at each of two different periods, 7-11 and 12-16 days of gestation (d.g.). The first represents the early period of organogenesis, when organs are beginning to form, and the second represents late organogenesis, a period of rapid growth and early maturation. The dams were sacrificed at $21 \mathrm{~d} . \mathrm{g}$ for assessments of embryolethality, malformations and fetal weights. Other animals were permitted to deliver and rear their young to 21 days of age. Some of these offspring were monitored postnatally for indices of physical maturation and development of neuromuscular reflexes.

Administration of LD, MD or HD at 7-11 d.g. did not significantly increase the incidence of malformations over that in the controls. Fetal weight was only affected at doses producing symptoms of maternal toxicity (inhibition of weight gain or death of some dams). The incidence 
of prenatal mortality was increased by all three materials, but again at doses producing some maternal toxicity.

These materials produced more severe fetal effects when administered at $12-16 \mathrm{~d} . \mathrm{g}$. than when given from $7-11 \mathrm{~d} . \mathrm{g}$. The frequency of prenatal mortality was increased by all three materials and the incidence of malformations was increased by HD (Table 6). The increased frequency of prenatal mortality occurred in the absence of signs of maternal toxicity but the increases in incidence of malformations produced by HD were accompanied by inhibited maternal weight gains during pregnancy. The principal malformations observed were cleft palate, immature lung and herniated diaphragms.

\section{METABOLISM AND DOSIMETRY}

(For greater detail, see Appendix F.)

Unlike the situation with radionuclides, relatively little is known about the biological disposition or the dosimetry of organic chemical mixtures. Yet, the information is needed in order to relate biological effects to the causative agents. This may be done at several levels. Administered dose expressed as $\mathrm{g} / \mathrm{kg}$ body weight may be sufficient if interest ends with the species of animal being used and if the substance being tested is pure. If a somewhat better, deeper understanding is required, a few relatively simple measurements of transfer and deposition may suffice. However, if the toxicological information being developed is to be extrapolated to other species, particularly man, much more detailed knowledge about the rate of absorption, clearance from the blood, tissue or organ accumulation, tissue or organ clearance and the biological transformation is needed. 
Table 6. Maternal and Fetal Toxicity in Rats Following Dosing with SRC-II Materials From 12-16 Days of Exposure.

\begin{tabular}{|c|c|c|c|c|c|c|c|c|c|c|}
\hline Agent & $\begin{array}{c}\text { Dose (a) } \\
(\mathrm{g} / \mathrm{kg} / \text { day })\end{array}$ & $\begin{array}{c}\text { Number } \\
\text { Dosed(c) }\end{array}$ & $\begin{array}{c}\% \\
\text { Dead(c) } \\
\end{array}$ & $\begin{array}{l}\begin{array}{l}\text { Number } \\
\text { Pregnant } \\
\text { at 21 d.g. }\end{array} \\
\end{array}$ & $\begin{array}{l}\text { Weight } \\
\text { Gain } \\
\text { to } 21 \text { d.g.(d) } \\
\end{array}$ & $\begin{array}{c}\% \\
\text { Implants } \\
\text { Resorbed(e) } \\
\end{array}$ & 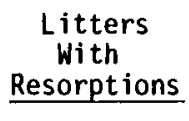 & $\begin{array}{c}\% \\
\text { Mal formed } \\
\text { Fetuses (e.g.) } \\
\end{array}$ & $\begin{array}{l}\text { Litters } \\
\text { With } \\
\text { Mal formed }(g) \\
\end{array}$ & 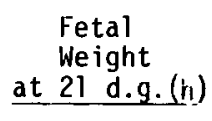 \\
\hline Corn 0il & -- & 14 & 0 & 12 & $148 \pm 31$ & $1(i)$ & 1 & 0 & 0 & $5.4 / 0.5$ \\
\hline Aroclor (b) & 0.11 & 13 & 0 & 10 & $101 \pm 24$ & 7 & 5 & 0 & 0 & $4.3 / 0.6$ \\
\hline $\begin{array}{l}\text { Light } \\
\text { Distillate }\end{array}$ & $\begin{array}{l}0.28 \\
0.56 \\
0.84 \\
1.12 \\
1.41 \\
1.69\end{array}$ & $\begin{array}{r}11 \\
12 \\
14 \\
6 \\
7 \\
5\end{array}$ & $\begin{array}{r}9 \\
8 \\
43 \\
67 \\
86 \\
80\end{array}$ & $\begin{array}{l}8 \\
9 \\
7 \\
1 \\
1 \\
1\end{array}$ & $\begin{array}{r}116 \pm 36 \\
101 \\
113 \pm 27 \\
32 \\
50 \pm 0 \\
112 \pm 0\end{array}$ & $\begin{array}{c}43(f) \\
23 \\
4(i) \\
-- \\
0\end{array}$ & $\begin{array}{r}4 \\
4 \\
3 \\
-- \\
20 \\
0\end{array}$ & $\begin{array}{r}2 \\
0 \\
1 \\
-1 \\
1 \\
0\end{array}$ & $\begin{array}{r}1 \\
0 \\
1 \\
-- \\
0 \\
0\end{array}$ & $\begin{array}{l}5.5 / 0.6 \\
5.5 / 0.5 \\
5.4 / 0.5 \\
4.7 / 0.2 \\
5.1 / 0.3\end{array}$ \\
\hline $\begin{array}{l}\text { Middle } \\
\text { Distillate }\end{array}$ & $\begin{array}{l}0.33 \\
0.65 \\
0.98 \\
1.30 \\
1.63 \\
1.96\end{array}$ & $\begin{array}{r}9 \\
11 \\
9 \\
6 \\
6 \\
3\end{array}$ & $\begin{array}{r}0 \\
9 \\
11 \\
33 \\
67 \\
100\end{array}$ & $\begin{array}{l}9 \\
7 \\
8 \\
4 \\
2 \\
0\end{array}$ & $\begin{array}{rl}127 & \pm 43 \\
149 & 32 \\
118 & \pm 40 \\
126 & \pm 19 \\
94 & \pm 36 \\
-- & \end{array}$ & $\begin{array}{l}5 \\
7 \\
20 \\
0 \\
0 \\
64 \\
--\end{array}$ & $\begin{array}{r}5 \\
5 \\
5 \\
0 \\
2 \\
--\end{array}$ & $\begin{array}{c}3 \\
0 \\
0 \\
0 \\
0 \\
--\end{array}$ & $\begin{array}{c}1 \\
0 \\
0 \\
0 \\
0 \\
--\end{array}$ & $\begin{array}{cll}5.8 & >0.6 \\
5.8 & >0.6 \\
5.1 & >0.4 \\
4.9 & >0.5 \\
4.5 & / & 0.4 \\
-- & \end{array}$ \\
\hline $\begin{array}{l}\text { Heavy } \\
\text { Distillate }\end{array}$ & $\begin{array}{l}0.37 \\
0.73 \\
1.10\end{array}$ & $\begin{array}{l}15 \\
13 \\
12\end{array}$ & $\begin{array}{r}0 \\
0 \\
17\end{array}$ & $\begin{array}{r}4 \\
10 \\
9\end{array}$ & $\begin{aligned} 129 & \pm 31 \\
85 & \pm 23 \\
76 & \pm 23\end{aligned}$ & $\begin{array}{l}9 \\
66 \\
69\end{array}(f)$ & $\begin{array}{l}7 \\
9 \\
9\end{array}$ & $\begin{array}{r}1 \\
74 \\
60\end{array}$ & $\begin{array}{l}2 \\
5 \\
6\end{array}$ & $\begin{array}{l}5.3 / 0.5 \\
4.3 / 0.7 \\
4.3 / 0.5\end{array}$ \\
\hline
\end{tabular}

\footnotetext{
(a) Administered by gavage once daily for five consecutive days; if undiluted, $0.1-1.2 \mathrm{ml}$ given per $300 \mathrm{~g}$ body weight.

(b) Diluted in corn oil and $1 \mathrm{ml}$ given per $300 \mathrm{~g}$ body weight.

c) Includes both pregnant and nonpregnant adult females

d) Body weight gain between 0 and 21 days of gestation (d.g.); mean + SD

e) Calculated on a per fetus rather than a per litter basis; includes resorbed and dead implants

f) One or more litters with all implants resorbed

(g) Combination of soft tissue and skeletal malformations

(h) Pooled means of each litter

(i) One or more dams delivered prematurely; implant data incomplete and not included
} 
Since our acute, subchronic and developmental toxicity studies involved the oral administration of test materials, we began our dosimetric studies by examining the absorption and distribution of components of PS after administration by gavage. In these studies, PS was administered to Wistar rats and blood samples obtained at times ranging from 15 minutes to 48 hours after administration. Animals were killed from 1-48 hours postadministration and tissues removed for analysis. Tissues were homogenized and extracted with pentane and extracts were analyzed by gas chromatography. The chromatograms obtained from the extracts were compared with those of PS to determine if the ratios of components in tissue samples were different from those in PS. Since PS contains a very large number of components, only a few major ones were studied initially. Compounds analyzed (concentration in percent given in parentheses) were: biphenyl (1.1\%), naphthalene $(1.0 \%)$, 2-methylnaphthalene $(4.3 \%)$, acenaphthene $(0.6 \%)$, and phenanthrene $(4.9 \%)$.

The rate of loss of materials from the stomach contents shows an inverse relationship to the molecular weight (Figure 8 ). These data also suggest that movement of these materials from the stomach is much slower than is usually found for stomach emptying (a few hours).

The highest concentrations of biphenyl, 2-methylnapththalene, and phenanthrene at 4,7 and 24 hours after oral administrations of PS were found in the fat (Table 7). The liver contained the next highest concentrations of these compounds and the highest concentrations of acenaphthene. The kidney had lower concentrations than the liver while the lung contained measurable concentrations of only 2-methylnaphthalene and phenanthrene at 7 and 24 hours after dosing. 


\section{LOSS OF COMPOUNDS FROM STOMACH CONTENTS}
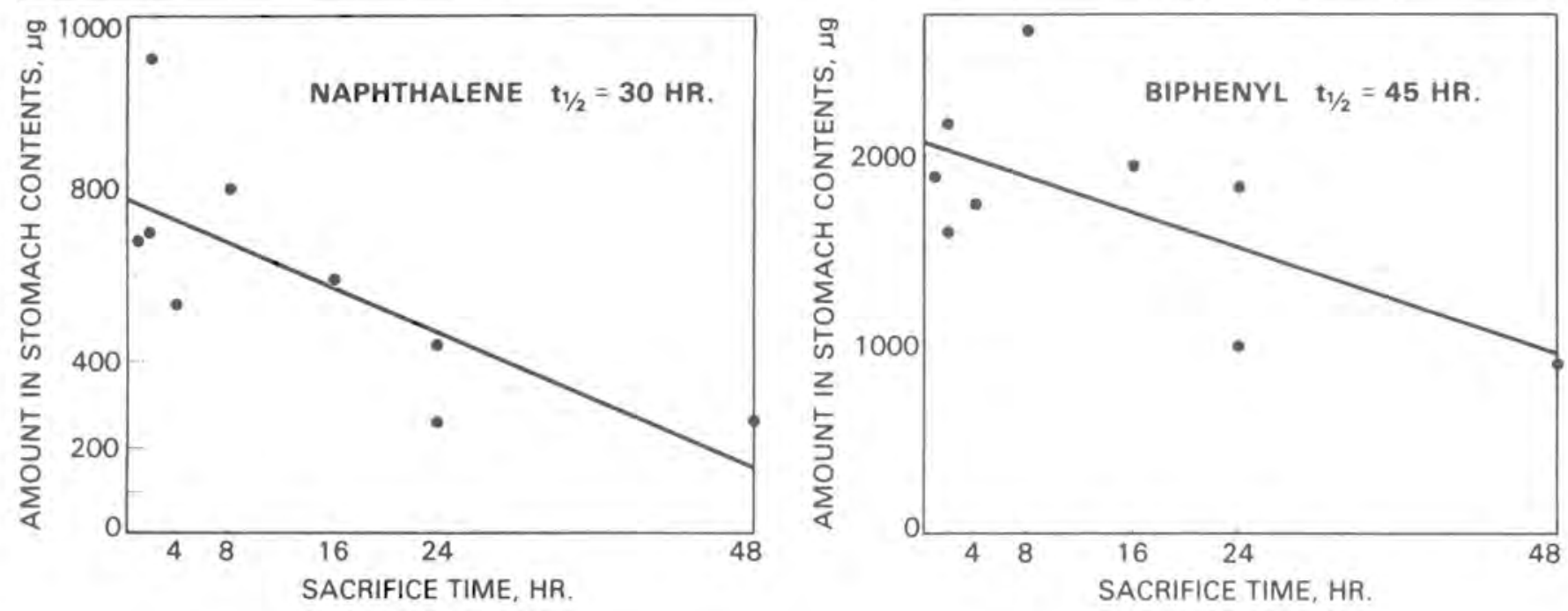

\section{HALF LIFE OF A COMPOUND IN THE STOMACH CONTENTS IS A FUNCTION OF ITS MOLECULAR WEIGHT}

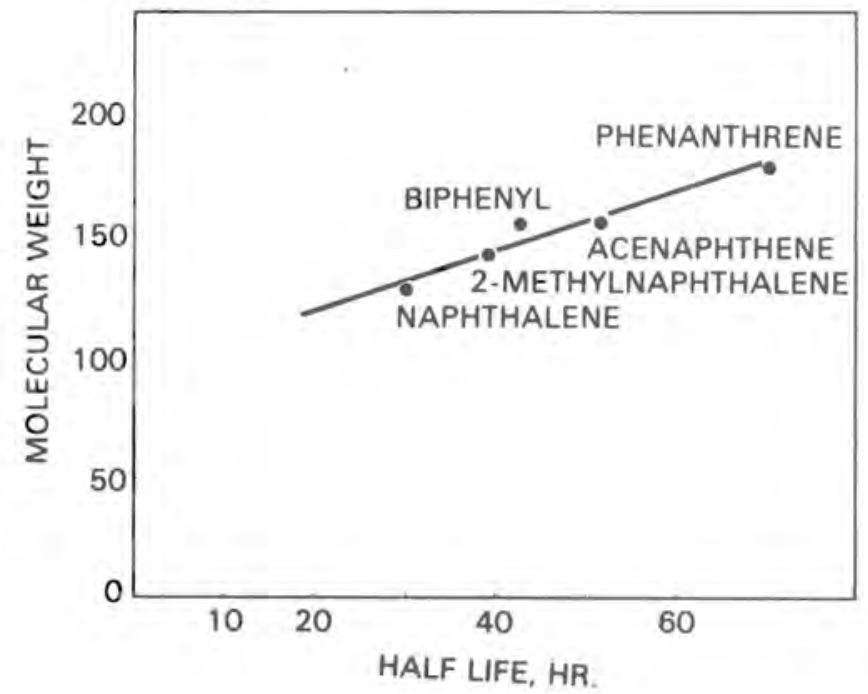

Figure 8. Half-1ife of a Compound in the Stomach Contents as a Function of its Molecular Weight. 
Table 7. Concentrations of Process Solvent Components in Tissues after Oral Administration.

Concentration $(\mu \mathrm{g} / \mathrm{g})$

Compound

Bipheny 1

2- methyl Naphthalene

Acenaphthene

Phenan threne

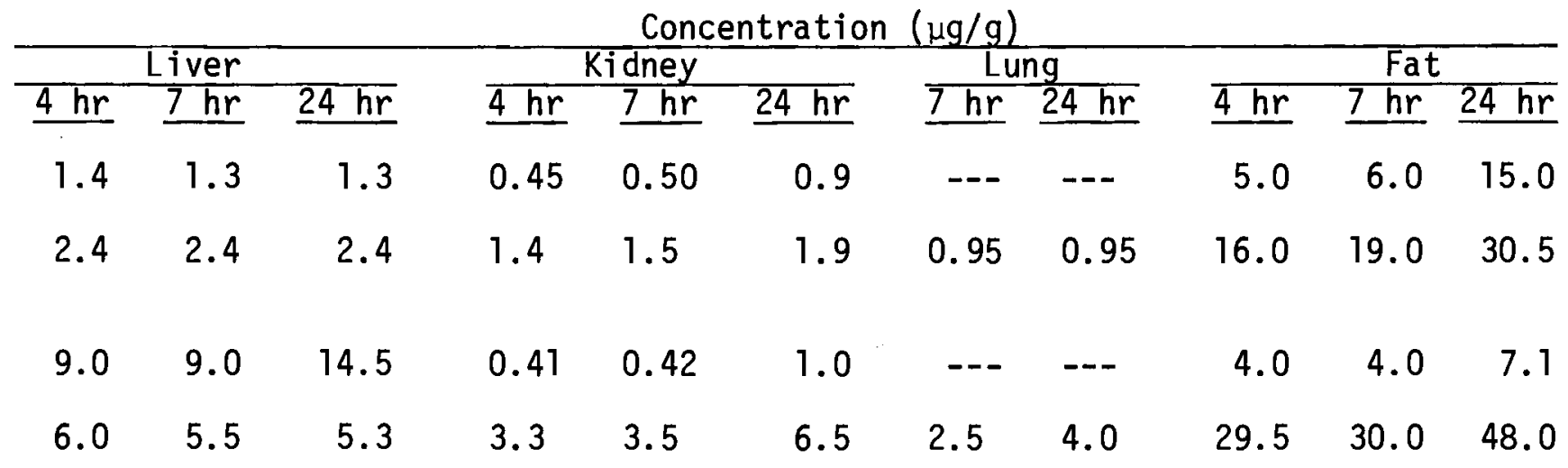


The concentrations of these materials in fat varied roughly according to their concentrations in PS. The concentrations in other tissues, however, were not directly related to the concentrations in the source material. These data, while they must be regarded as preliminary, illustrate the complexity of the problem of dosimetry with multicomponent mixtures.

\section{DISCUSSION OF ANIMAL TOXICOLOGY AND DOSIMETRY}

The SRC-II materials used in this study, LD, MD, and $H D$, have analogs in SRC-I LO, WS, and PS, respectively, since similar boilingpoint ranges are represented. The toxicities, however, are different, particularly between MD and WS, with WS being 6-7 times more toxic than MD. Smaller differences are found between $L D$ and $L O$ and between HD and PS, suggesting similarities in chemical composition for these pairs of materials. The reasons for the difference in $L D_{50}$ values for $M D$ and $W S$ are not entirely resolved but appear to be related to a higher phenolic content for WS. All SRC materials studied to date fall into the category of being moderately toxic according to standard industrial classifications.

Although the prenatal animal is often significantly more sensitive to toxic agents than is the adult, our data do not indicate a greatly enhanced sensitivity of the embryo or fetus to SRC-II materials. Prenatal mortality was increased by $L D, M D$, and $H D$ after administration from 12-16 d.g. However, for LD and MD, doses were required which approach those which produce maternal toxicity. The increased incidence of malformations induced by $H D$ also required doses high enough to produce 
signs of maternal toxicity. Our results thus far suggest that the risk for the fetus is only slightly greater than for the mother.

The investigations on the absorption and distribution of PS components in the rat are very preliminary. Nonetheless, they provide the beginnings of a method for constructing a moder to compare the biologic disposition of different materials entering the body by various routes in different animal species. Actual construction of a model will, of course, require a substantially larger data base. 


\title{
5.0 IMPLICATIONS OF EXPERIENCE AND \\ FINDINGS TO DATE
}

\begin{abstract}
The major thrust of PNL effort to date has been formative; accordingly, in-depth analysis of a generic set of samples of SRC-II materials has been stressed. However, experiences and findings even at this early stage of PNL program development and execution have significant implications for future SRC characterization and process development.
\end{abstract}

Biological Activity of SRC-II Materials

Results to date indicate that at least some unrefined SRC-II materials produced during plant startup, stable operation, and/or process upset are biologically active. This is in substantive agreement with earlier biological results on heavy coal liquids produced by other processes.

Sample Representativeness in SRC Characterization

Further quantification of the chemical and biological properties of anticipated demonstration-scale SRC materials will require the use of highly representative PDU- and pilot-scale samples. Close and active process engineering support will be required to manage the definition and collection of such samples.

\section{Tiered Characterization of Biological Properties}

Microbial (notably the Ames test) and mammalian cell tests offer relatively rapid, inexpensive means for initial screening of samples for 
potential biological activity. However, experience with SRC materials demonstrates the need for such tests to be performed in combinations to provide reasonable reliability. Moreover, given the present state of knowledge, significant results of such testing must also be confirmed by selective testing in animals. Nonetheless, when used properly and in a screening context, the cellular assay systems (particularly the Ames test) are powerful tools to aid in the evaluation of large numbers of materials and in determining the effects of process conditions on these materials.

Approaches to Mitigation of Biological Activity in SRC Materials

Direct evidence of the biologically active character of at least some SRC raw materials suggests the need for effective means for SRC materials management.

Concurrent with PNL's development of substantive evidence regarding the biological activity of SRC-II materials, DOE has been investigating a range of strategies which might mitigate the biological effects of raw SRC-II materials. These include among other alternatives: (a) protocols for special marketing and handling of identified toxic products; (b) raw product refining for upgrading (e.g., catalytic and noncatalytic hydrotreating), and (c) optimization of process operations to minimize the production of toxic materials. To date, these studies have been 1 imited to process engineering studies. Plans are already underway to incorporate studies by PNL using its protocols for biological testing in both process optimization and raw product upgrading studies. 
No. of

Copies

3 R. E. Clusen

Assistant Secretary for the Environment

Department of Energy

Washington, D.C. 20545

1 C. E. Carter

Scientific Director

NIEHS

P.0. Box 12233

Research Triangle Park, NC 27709

132 Paul Duhamel

Office of the Assistant Secretary for the Environment

Department of Energy

Washington, D.C. 20545

132 Larry Joseph

Office of the Assistant Secretary for Energy Technology

Department of Energy

Washington, D.C. 20545

27 DOE Technical Information Center

1 L. R. Harris

National Institute 0ccupational Safety \& Health

Mail Stop 8A-45

5600 Fishers Lane

Rockville, MD 20857

1 R. L. Scott

USDOE/PETC

4800 Forbes Avenue

Pittsburgh, PA 15213

25 D. K. Schmalzer

Gulf Mineral Resources Co.

1720 S. Bellaire

Denver, C0 80222

25 M. J. Massey

Environmental Research \&

Technology, Inc.

700 Fifth Avenue Building

Fourth Floor

Pittsburg, PA 15219
1 C. H. Hobbs

Lovelace Inhalation Toxicology Research Institute

P. 0. Box 5890

A1buquerque, NM 87115

1 J. Norwood

Air Products and Chemicals

P. 0. Box 538

Allentown, PA 18105

1 C. Reilly

Biology Department

Argonne National Laboratory

9700 South Cass Ave.

Argonne, IL 60439

1 K. Cowser

Oak Ridge National Laboratory

P. 0. Box $X$

Oak Ridge, TN 37830

1 U. P. Bond

Brookhaven National Laboratory Upton, Long Island, NY 11973

1 C. R. Richmond

Oak Ridge National Laboratory

P. 0. Box X

Oak Ridge, TN 37830

1 W. K. Sinclair

Argonne National Laboratory

9700 South Cass Avenue

Argonne, IL 60439

1 E. L. Alpen

Lawrence Berkeley Laboratory

University of California

Building 90, Room 2056

No. 1 Cyclatron Road

Berkeley, CA 94720

1 M. L. Mendel sohn

University of California

Lawrence Livermore Laboratory

P. 0. Box 808

Livermore, CA 94550

1 A.A. Churm

DOE Patent Division

9800 S. Cass Avenue

Argonne, IL 60439 


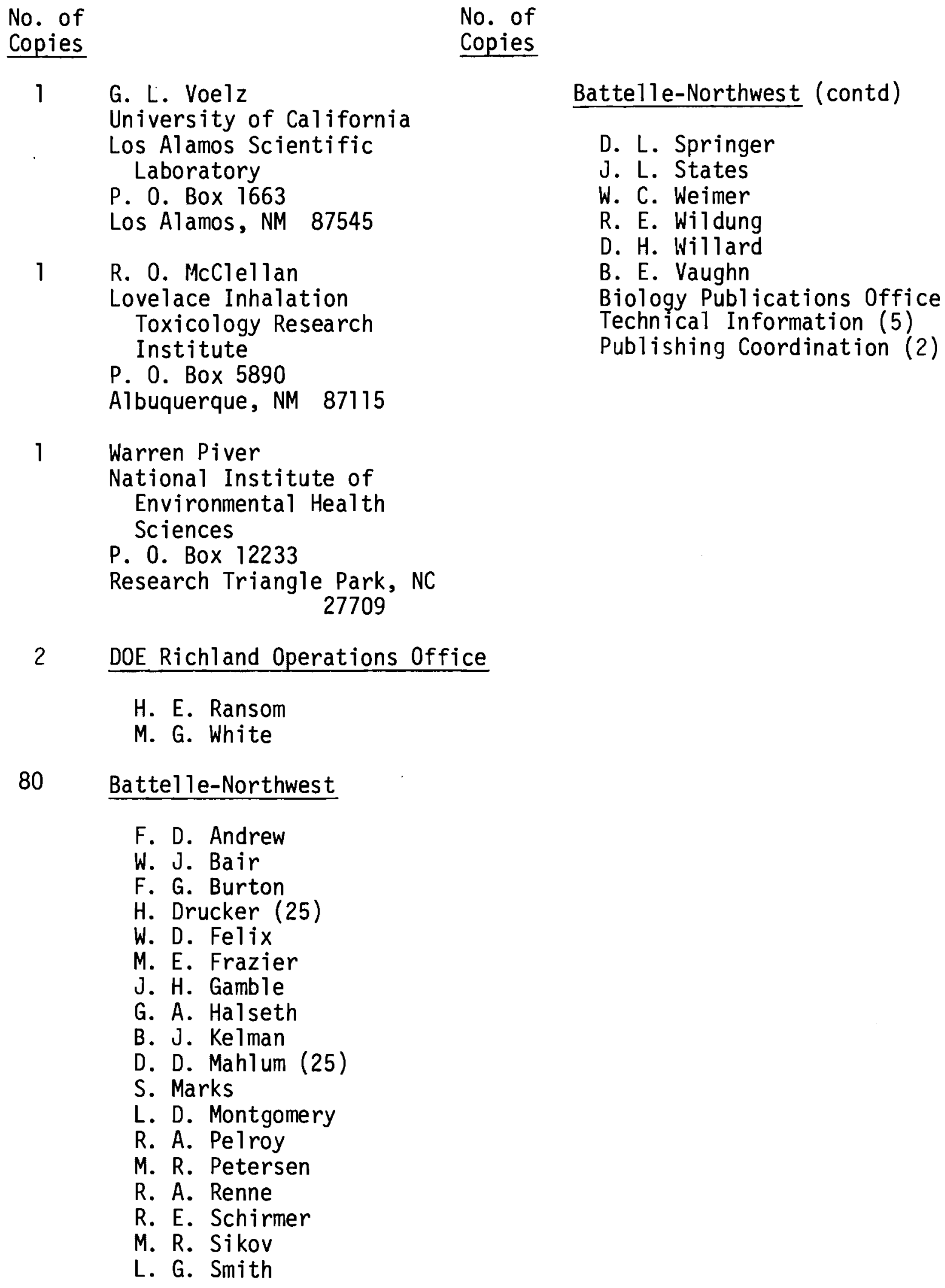

2 DOE Richland Operations Office

H. E. Ransom

M. G. White

80 Battelle-Northwest
F. D. Andrew
W. J. Bair
F. G. Burton
H. Drucker (25)
W. D. Felix
M. E. Frazier
J. H. Gamble
G. A. Halseth
B. J. Kelman
D. D. Mahlum (25)
S. Marks
L. D. Montgomery
R. A. Pelroy
M. R. Petersen
R. A. Renne
R. E. Schirmer
M. R. Sikov
L. G. Smith

Battelle-Northwest (contd)

D. L. Springer

J. L. States

W. C. Weimer

R. E. Wildung

D. H. Willard

B. E. Vaughn

Biology Publications Office

Technical Information (5)

Publishing Coordination (2) 